\author{
Izv. prof. dr. sc. Frane Staničić ${ }^{1}$ \\ Pravni fakultet Sveučilišta u Zagrebu \\ Izv. prof. dr. sc. Bosiljka Britvić Vetma² \\ Pravni fakultet Sveučilišta u Splitu
}

\title{
PRIMJENA DIREKTIVE O USLUGAMA U SUSTAVU VISOKOG OBRAZOVANJA
}

\author{
UDK: $339: 378$ \\ DOI: $10.31141 /$ zrpfs.2020.57.135.157 \\ Izvorni znanstveni rad \\ Primljeno: 1. studenog 2019.
}

Autori u radu analiziraju primjenjuje li se Direktiva 2006/123/EZ Europskog parlamenta i Vijeća od 12. prosinca 2006. godine o uslugama na unutarnjem tržištu i na sustav visokog obrazovanja. U radu će prikazati postojeća teorijska razmatranja o toj problematici, kao i praksu Suda Europske unije. Autori će pokazati da se radi o iznimno složenoj problematici oko koje ne postoji konsenzus u teoriji, a postojeća praksa Suda Europske unije daje odgovore na određena pitanja, ali na niz pitanja koja se mogu postaviti glede eventualne primjene ove Direktive na sustav visokog obrazovanja Sud nije odgovorio. Sintezom teorije i prakse autori će pokazati da, prema njihovu mišljenju, navedena Direktiva nije primjenjiva na sustav javnog visokog obrazovanja. Odnosno, teza autora jest da je sustav visokog obrazovanja isključivi prerogativ država članica koje samostalno odlučuju kakav sustav visokog obrazovanja žele imati.

Ključne riječi: visoko obrazovanje, privatno, javno, financiranje, usluge

\section{UVOD}

Direktivom 2006/123/EZ Europskog parlamenta i Vijeća od 12. prosinca 2006. godine o uslugama na unutarnjem tržištu (dalje u tekstu: Direktiva o uslugama), ${ }^{3}$ kako joj je proklamirani cilj, željelo se osigurati „konkurentno tržište usluga“ jer ono ima ključnu važnost za promicanje gospodarskog rasta i stvaranje novih radnih mjesta u Europskoj uniji. Pri njezinu donošenju navodilo se da usluge predstavljaju motor gospodarskog rasta i odgovorne su za $70 \%$ BDP-a i zaposlenosti u većini država članica, pa je nužno ukloniti pravne zapreke za uspostavu pravog unutarnjeg

\footnotetext{
Izvanredni profesor na Katedri za upravno pravo Pravnog fakulteta Sveučilišta u Zagrebu.

2 Izvanredna profesorica na Katedri za upravno pravo Pravnog fakulteta Sveučilišta u Splitu.

3 Službeni list Europske unije L 376/36 od 27. prosinca 2006.
} 
tržišta. ${ }^{4}$ Direktivom o uslugama uređuje se sloboda poslovnog nastana i slobodno kretanje usluga, međutim, što treba posebno naglasiti, samo u onoj mjeri u kojoj su djelatnosti na koje se odnosi otvorene za tržišno natjecanje. Odnosno, u samoj Direktivi o uslugama se ističe da je potrebno održati pravilnu ravnotežu između otvaranja tržišta i očuvanja javnih usluga.

Stoga je, za našu temu, ključno pitanje primjenjuje li se Direktiva o uslugama na područje visokog obrazovanja ili ne, a ako da, u kojoj mjeri. Naime, pojavljuju se, za potrebe ovoga rada primarno u našem domaćem kontekstu, ali i u Europi, pa i svijetu, prijepori oko toga je li područje visokog obrazovanja „,na tržištu“, pa prema tome i posljedično, primjenjuje li se Direktiva o uslugama. Odnosno, postoji li onda, prema sadašnjem stanju stvari, nelojalna konkurencija između igrača na tržištu? Ukoliko postoji, onda je očito da je hrvatski pravni poredak neadekvatno implementirao Direktivu o uslugama i da su potrebne zakonodavne promjene. Ukoliko ne postoji, onda su takvi zahtjevi koji se uistinu pojavljuju u procesu donošenja novog paketa zakona koji u Republici Hrvatskoj uređuju znanost i visoko obrazovanje deplasirani i treba ih odbiti.

Ponajprije, treba naglasiti da ovo pitanje nije ni u kojem slučaju jednoznačno odgovoreno, niti u teoriji, niti u sudskoj praksi. Zanimljivo je spomenuti konferenciju upravo na ovu temu koja se održala 2014. godine u Portugalu sa zanimljivim naslovom: „Konferencija o visokom obrazovanju kao tržištu: prekogranično obrazovanje i Direktiva o uslugama“. ${ }^{5}$ Treba spomenuti i vrlo zanimljivu knjigu iz 2018. godine naziva „Europsko visoko obrazovanje i unutarnje tržište: tenzije između europskih politika i nacionalnog suvereniteta". ${ }^{6}$ Navodimo ove podatke kako bismo pokazali da se radi o iznimno osjetljivom pitanju koje nadilazi domaće granice i kako se radi o pitanju koje je aktualno u Europskoj uniji. Naglašavamo da je naša polazna hipoteza da se Direktiva o uslugama ne primjenjuje na sustav javnog obrazovanja koji je u strogoj i isključivoj nadležnosti država članica (dakako, ako država članica tako odabere, ništa je ne sprečava da u potpunosti prihvati primjenu Direktive).

\footnotetext{
4 „Budući da usluge predstavljaju motor gospodarskog rasta i odgovorne su za $70 \%$ BDP-a i zaposlenosti u većini država članica, ova fragmentacija unutarnjeg tržišta negativno utječe na cjelokupno europsko gospodarstvo, a posebno na konkurentnost malih i srednjih poduzeća te na kretanje radnika, dok potrošačima onemogućava pristup većem izboru usluga s konkurentnim cijenama. ... Europski parlament i Vijeće naglasili su da uklanjanje pravnih zapreka za uspostavu pravog unutarnjeg tržišta ima prioritetnu važnost za ostvarivanje cilja, ..., koji uključuje povećanje zaposlenosti i socijalne kohezije te ostvarivanje održivog gospodarskog rasta, da bi do 2010. Europska unija postala najkonkurentnije i najdinamičnije svjetsko gospodarstvo utemeljeno na znanju osiguravajući veću zaposlenost i bolja radna mjesta. ... Iz tog je razloga važno uspostaviti unutarnje tržište usluga održavajući pravilnu ravnotežu između otvaranja tržišta i očuvanja javnih usluga te socijalnih i potrošačkih prava."

5 Conference on Higher Education as Commerce: Cross Border Education and the Service Directive, podaci dostupni na https://www.a3es.pt/en/events/conference-higher-education-commerce-cross-bordereducation-and-service-directive, pristupljeno 8. XI. 2019.

6 Sin, C., Tavares, O., Cardoso, S., J. Rosa, M. (ur.), European Higher Education and the Internal Market, Palgrawe Macmillan, London, 2018.
} 


\section{ULOGA EUROPSKE UNIJE U VISOKOM OBRAZOVANJU}

Ugovor o funkcioniranju Europske unije ne daje izravne nadležnosti EU-u u području visokog obrazovanja. Općenito govoreći, u ugovorima koji čine primarno pravo Unije ima vrlo malo pravnih odredbi vezanih za (visoko) obrazovanje. ${ }^{7}$ Uključivanje (visokog) obrazovanja u primarno europsko pravo novijeg je datuma, od uspostave Unije 1992. godine. ${ }^{8}$ Visoko obrazovanje navedeno je u dva članka UFEU-a: čl. $6 .{ }^{9}$ i. čl. $165 .{ }^{10}$ Međutim, ove odredbe ne definiraju uistinu načela

7 Ravinet, P., „On Principles, Europe and Higher Education: Reflections on European Higher Education as an Intersecting Normative Space“, u: Sin, C., Tavares, O., Cardoso S. J., Rosa M., (ur.), op. cit., str. 25.

8 Vidi o ulozi EU-a u području visokog obrazovanja i u: van Wageningen, A., „,The Legal Constitution of Higher Education Policy and Governance of the European Union“, u: Huisman, J., de Boer, H., Dill, DD, Souto-Otero, M. (ur.), The Palgrave International Handbook of Higher Education Policy and Governance, Palgrave Macmillan, London, 2015., str. 95-113.

9 „Unija je nadležna za poduzimanje djelovanja kojima se podupiru, koordiniraju ili dopunjuju djelovanja država članica. Na europskoj se razini takvo djelovanje odnosi na sljedeća područja:

(a) zaštitu i poboljšanje zdravlja ljudi;

(b) industriju;

(c) kulturu;

(d) turizam;

(e) obrazovanje, strukovno obrazovanje, mlade i sport;

(f) civilnu zaštitu;

(g) administrativnu suradnju."

10 ,1. Unija doprinosi razvoju kvalitetnog obrazovanja poticanjem suradnje među državama članicama te, ako je to potrebno, podupiranjem i dopunjavanjem njihovih aktivnosti, pri čemu u potpunosti poštuje odgovornost država članica za nastavni sadržaj i ustroj obrazovnih sustava te njihovu kulturnu i jezičnu raznolikost.

Unija doprinosi promidžbi europskog sporta, vodeći pritom računa o specifičnoj prirodi sporta, njegovim strukturama koje se temelje na dobrovoljnim aktivnostima te njegovoj društvenoj i obrazovnoj ulozi.

2. Ciljevi su djelovanja Unije:

- razvoj europske dimenzije u obrazovanju, osobito nastavom i popularizacijom jezika država članica,

- poticanje mobilnosti studenata i nastavnika, između ostalog, poticanjem akademskog priznavanja istovrijednosti diploma i trajanja studija,

- promicanje suradnje između obrazovnih ustanova,

- razvoj razmjene informacija i iskustava u vezi s pitanjima koja su zajednička obrazovnim sustavima država članica,

- poticanje razvoja razmjene mladih i razmjene društveno-pedagoških radnika te poticanje sudjelovanja mladih u demokratskom životu Europe,

- poticanje razvoja obrazovanja na daljinu,

- razvijanje europske dimenzije u sportu promicanjem pravednosti i otvorenosti na sportskim natjecanjima i suradnje među tijelima odgovornima za sport te zaštitom tjelesnog i moralnog integriteta sportaša i sportašica, osobito najmlađih sportaša i sportašica.

3. Unija i države članice podupiru suradnju s trećim zemljama i međunarodnim organizacijama nadležnima u području obrazovanja i sporta, osobito s Vijećem Europe.

4. Kako bi doprinijelo ostvarivanju ciljeva iz ovog članka:

- Europski parlament i Vijeće, odlučujući u skladu s redovnim zakonodavnim postupkom i nakon savjetovanja s Gospodarskim i socijalnim odborom te Odborom regija, donosi poticajne mjere, pri čemu je isključeno bilo kakvo usklađivanje zakona i drugih propisa država članica,

- Vijeće, na prijedlog Komisije, donosi preporuke.“ 
europske obrazovne politike. ${ }^{11}$ Ipak, Sud Europske unije legitimizirao je pravo Unije da „uđe“ u ovo područje kako bi se ostvario cilj integracije tržišta. Prvi slučaj u kojemu je to Sud učinio bio je Casagrande ${ }^{12}$ kada je Sud zaključio da se progresivna implementacija zajedničkog tržišta ne može ometati činjenicom da je u području obrazovanja nadležnost rezervirana isključivo za države članice. Odnosno, ovom je presudom sud implicitno priznao da obrazovanje može biti instrument za implementiranje ekonomske integracije. ${ }^{13}$ Sud je istaknuo: ,iako je obrazovna politika kao takva izvan sfera koje je Ugovor povjerio institucijama Zajednice, iz toga ne slijedi da je izvršavanje ovlasti povjerenih Zajednici na neki način ograničeno ako je takve naravi da zahvaća mjere koje se poduzimaju u izvršavanju obrazovne politike“ (par. 12.). Kako navodi Gori, zaključak Suda implicira da je, kako bi se ostvario cilj ekonomske integracije, potpuno prihvatljivo da Zajednica intervenira u organizaciju nacionalnog obrazovanja. ${ }^{14}$ Ipak, treba naglasiti da Sud nije izrijekom ovo istaknuo, nego se radi o tumačenju njegove odluke i ,implicitnom“ davanju te mogućnosti Zajednice. Nakon predmeta Casagrande Sud je u više navrata pojašnjavao svoje viđenje ove problematike, o čemu više vidi infra. Uopćeno rečeno, uglavnom je tumačio, vrlo široko, pravo slobode kretanja i slična temeljna prava u pravu Unije (tada Zajednice). ${ }^{15}$ Ravinet naglašava da je povezivanje visokog obrazovanja i europskog tržišta bilo taktičko, kako bi se postavila pravna osnova za razvijanje inicijativa u području visokog obrazovanja. ${ }^{16}$

Iako, kako je već naglašeno, visoko obrazovanje nije, u osnovi, u nadležnosti Europske unije, Europska Komisija (dalje u tekstu: EK) pokušava pokrenuti raspravu o politici Unije za visoko obrazovanje, pri čemu posebno ističemo Komunikaciju Komisije prema Europskom parlamentu, Vijeću, Europskom ekonomskom i socijalnom odboru i Odboru regija od 30. svibnja 2017. godine. ${ }^{17}$ Naime, ta Komunikacija nosi podnaslov: „o obnovljenoj agendi EU-a za visoko obrazovanje“. U njoj EK ističe jedinstvenu ulogu koju visoko obrazovanje ima za budućnost europskog projekta. Bez ustanova visokog obrazovanja i sustava koji sudjeluju u obrazovanju, istraživanjima i inovacijama Europa ne može odgovoriti na izazove koji se nalaze pred njom. ${ }^{18}$ Ipak, EK ističe da je reforma visokog obrazovanja

11 Ravinet, P., op. cit., str. 26.

12 Donato Casagrande v Landeshauptstadt München, C-9/74 od 3. srpnja 1974. Tužitelju je bilo zabranjeno dobivanje stipendije za pohađanje škole u Njemačkoj jer je bio talijanski državljanin. U sporu se postavilo pitanje spada li stvar uopće pod primjenu europskog prava s obzirom na to da je obrazovanje domaine reserve država članica. Sud je na kraju prihvatio primjenjivost EU-prava.

13 Vidi u: Gori, G., Towards a EU Right to Education, Kluwer Law International, The Hague, London, Boston, 2001., str. 26. i 27.

14 Ibid., str. 27

15 Vidi, primjerice, predmete Lair v, Universität Hanover, C-39/86 od 21. lipnja 1988. i Annunziata Matteucci v Communauté française of Belgium and Commissariat général aux relations internationales of the Communauté française of Belgium, C-235/87 od 27. rujna 1988.

16 Ravinet, P., op. cit., str. 28.

17 Communication from the Commission to the European Parliament, the Council, the European Economic and Social Committee and the Committee of the Regions - on a renewed EU agenda for higher education, dostupno na https://eur-lex.europa.eu/legal-content/EN/TXT/PDF/?uri=CELEX:52017DC024 7\&from=DA, pristupljeno 8. XI. 2019.

18 Ibid., str. 2. 
odgovornost država članica, ali u čemu im EU može pomoći, što EK želi osigurati svojom aktivnošću. EK ističe da su strateški pravci koje EU i države članice moraju ostvariti: izgradnja baza podataka o uspjesima u visokom obrazovanju (obrazovanju, istraživanjima, inovacijama i dizajnu sustava; podrška suradnji, zajedničkom učenju i ciljanoj politici savjetovanja između vlada i onih ovlaštenih za upravljanje visokim obrazovanjem; jačanje kapaciteta i izlaza (outputs) ustanova visokog obrazovanja; podrška međunarodnoj mobilnosti studenata, osoblja i istraživača te jačanje suradnje između visokog obrazovanja, istraživanja i biznisa). ${ }^{19}$ Stoga EK ističe da su prioriteti u pristupu visokom obrazovanju EU-a (država članica) sljedeći: borba protiv neodgovarajućeg razvoja vještina i promocija izvrsnosti u razvoju vještina, ${ }^{20}$ izgradnja inkluzivnih $\mathrm{i}$ povezanih sustava visokog obrazovanja, ${ }^{21}$ osiguranje doprinosa ustanova visokog obrazovanja inovacijama ${ }^{22}$ i podrška efektivnim i efikasnim sustavima visokog obrazovanja. ${ }^{23}$ Kako bi se ovi prioriteti ostvarili, EK ce inicirati dijalog o implementaciji svih navedenih aktivnosti sa svim dionicima, uključujući države članice, Europski parlament, Odbor regija, Ekonomski i socijalni odbor i Europsku investicijsku banku.

\section{RAZLIKOVANJE JAVNE SLUŽBE, USLUGA OD OPĆEG INTERESA, USLUGA OD OPĆEG GOSPODARSKOG INTERESA I NEGOSPODARSKIH USLUGA OD OPĆEG INTERESA}

Za našu temu potrebno je provesti razlikovanje temeljnih pojmova: usluga od općeg interesa, gospodarskih usluga od općeg interesa i negospodarskih usluga od općeg interesa. Kako o tome postoji literatura velikog opsega, to ćemo, samo za potrebe ovoga rada ukratko prikazati razliku između navedenih pojmova. EK je pokušao sustavno pristupiti konceptu javnih službi u Zelenoj knjizi o službama od općeg interesa (Green paper on services of general interest) iz svibnja $2003 .{ }^{24}$ Zelena knjiga razlikuje gospodarske od negospodarskih službi od općeg interesa, kako u

19 Ibid., str. 3.

20 Obveza je sustava visokog obrazovanja osigurati ažurne sadržaje, relevantne studijske programe. Stoga će EK pokrenuti europsku inicijativu praćenja završenih studenata, pokrenuti koaliciju EU STEM, potaknuti integraciju radnih mjesta prepoznatu kroz ECTS-bodove u programe visokog obrazovanja, razviti i pokrenuti model digitalne spremnosti i pokrenuti stratešku podršku za nastavnike, doktorske kandidate i poslijedoktorande kroz Erasmus+.

21 EK će upravljati podrškom Erasmusa+ kako bi pomogla visokim učilištima u razvoju integriranih institucionalnih strategija za inkluzivnost, rodnu ravnopravnost i uspjeh u studiju, promicati razvoj i testiranje fleksibilnih i modularnih sadržaja, podržavati visoka učilišta u dodjeli ECTS-bodova studentima za volontiranje i društveni rad te podržavati priznanje kvalifikacija izbjeglica.

${ }^{22}$ EK će proširiti model EIT-RIS (regionalna inovacijska shema), podržati razvoj i testiranje metoda poučavanja u svrhu postizanja kreativnosti i inovacija u visokom obrazovanju, istaknuti ulogu visokog obrazovanja za „pametne specijalizacije“, pojačati sustav „Marie Sklodowska-Curie“, povećati podršku Unije za suradnju biznisa i sveučilišta.

23 Communication... op. cit., str. 4.

24 Đulabić, V., „Povelje javnih službi: pokušaj podizanja kvalitete javne uprave i jačanja uloge građana“, Zbornik Pravnog fakulteta u Zagrebu, vol. 56 (2006.), 1, str. 34. 
pogledu njihova klasificiranja, tako i u pogledu uređenja njihova pravnog položaja. ${ }^{25}$ Nakon toga slijedila je Bijela knjiga o uslugama od općeg interesa. ${ }^{26}$ Izraz „usluge od općeg interesa" ne postoji u samome Ugovoru. U praksi Europske zajednice izveden je iz izraza „usluge od općeg gospodarskog interesa“ koji se koristi u Ugovoru. Izraz „usluge od općeg interesa“ širi je od izraza „usluge od općeg gospodarskog interesa“ te pokriva i tržišne i netržišne službe koje vlasti označe kao službe od općeg interesa podložne posebnim obvezama što ih imaju javne službe. ${ }^{27}$ Izrazi „,usluga od općeg interesa“ $i$, ,usluga od općeg gospodarskog interesa" ne smiju se pomiješati s izrazom „javna služba“. Taj je izraz manje precizan i može imati različita značenja koja pak mogu prouzročiti nejasnoće i nesporazume. Izraz se katkada odnosi na činjenicu da se usluga nudi javnosti, katkada pak naglašava da je nekoj službi dodijeljena posebna uloga od javnog interesa, a katkada se odnosi na vlasništvo ili na status tijela koje uslugu prža. ${ }^{28}$ Važno je naglasiti da pravo Unije izričito ne definira što je usluga od općeg gospodarskog interesa, nego je odluka o uvođenju konkretnih usluga od općeg gospodarskog interesa, njihovoj naravi i dosegu načelno prepuštena širokoj diskreciji država članica. ${ }^{29}$ Pojam negospodarskih usluga od općeg interesa pojavio se pak - doduše, bez definicije - najprije u Komisijinim neobveznim aktima, poput Komisijine interpretativne komunikacije o koncesijama u skladu s pravom Zajednice, zatim u članku 2. stavku 2. točki (a) Direktive o uslugama na unutarnjem tržištu, a na kraju i u članku 2. Protokola br. 26 UFEU-a o uslugama od općeg interesa, dodanom na temelju Lisabonskog ugovora iz 2007., i do danas nema veće značenje. ${ }^{30}$ Dakle, dok izraz javna usluga ili služba (,,service public") $)^{31}$ potječe iz francuskog upravnog prava i označava sve javne usluge ili njihove pružatelje, $u$

25 Ibid

26 White Paper on services of general interest (2004.), dostupno na: https://eur-lex.europa.eu/legalcontent/EN/TXT/?uri=LEGISSUM\%3Al23013b, pristupljeno 10. XI. 2019. Prijevod ovog dokumenta na hrvatski jezik vidi u: Bijela knjiga Europske unije o službama od općeg interesa - prijevod, i. dio, Hrvatska javna uprava, vol. 6 (2006.) 4, str. 35-49.

27 Ibid.

28 Ibid.

29 Stanković, D., „Uloga postupaka javne nabave u financiranju usluga od općeg gospodarskog interesa“, Zagrebačka pravna revija, vol. 7 (2108.), 1, str. 56.

$30 \quad$ Ibid., str. 57.

31 ,Zbog toga javna vlast snosi krajnju odgovornost za njihovo obavljanje. Javne službe moguće je klasificirati na komercijalne (gospodarske) i nekomercijalne (negospodarske). U prvom je slučaju riječ o službama koje se, velikim dijelom, mogu orijentirati na mehanizme tržišta, ali se njima istodobno zadovoljava širi, tj. javni interes. Kod takvih službi, dakle, nije riječ isključivo o tržišnom pružanju usluga onima koji su sposobni takve usluge kupiti, nego o uslugama za funkcioniranje kojih je odgovorna država. Takve se službe ne mogu, ni u kojem slučaju, potpuno prepustiti mehanizmima tržišta. Tijela javne vlasti imaju određenu odgovornost u pogledu gospodarskih javnih službi. Ta se odgovornost očituje u potrebi regulacije takvih djelatnosti ... tako da postavi standarde obavljanja tih službi. ... Druga kategorija javnih službi su negospodarske, tj. nekomercijalne javne službe. Njihova je temeljna karakteristika obavljanje javnih poslova kojima se osigurava zadovoljavanje određenog javnog interesa bez izričite namjere stjecanja dobiti. Riječ je o društveno korisnim i potrebnim službama koje nisu primarno usmjerene na mehanizme tržišta. Takve se službe vrlo često ne bi mogle obavljati kad subjekti javne vlasti ne bi bili odgovorni za njihovo obavljanje. Njihovo obavljanje opravdava se činjenicom postojanja javnog interesa za takvim službama. ... U tu kategoriju javnih službi moguće je ubrojiti različite službe poput zdravstvenog i socijalnog osiguranja, obrazovanja te društvene, tehničke, statističke i druge službe negospodarske prirode."Vidi u: Đulabić, V., op. cit., str. 32. i 33. 
pravu Unije ponajprije se govori o uslugama od općeg interesa, koje pak mogu biti gospodarske ili negospodarske, poput usluga osnovnog obvezatnog obrazovanja. ${ }^{32}$

\section{PRAKSA SUDA EUROPSKE UNIJE O PRIMJENI DIREKTIVE O USLUGAMA NA SUSTAV VISOKOG OBRAZOVANJA}

Treba naglasiti i da je samom Direktivom o uslugama izrijekom propisano da se ona primjenjuje samo na usluge koje se pružaju u zamjenu za ekonomsku naknadu. Pritom Direktiva dalje navodi kako usluge od općeg interesa nisu obuhvaćene u definiciji iz članka 50. Ugovora o funkcioniranju Europske unije te stoga ne ulaze u područje primjene ove Direktive. Također je propisano kako se ona ne primjenjuje niti na negospodarske usluge od općeg interesa, pa bi se moglo zaključiti da se primjenjuje na gospodarske usluge od općeg interesa. Ukratko, moglo bi se zaključiti da je ključni kriterij prema kojemu bismo mogli zaključiti primjenjuje li se Direktiva o uslugama onaj radi li se o „poduzetniku“ u smislu prava tržišnog natjecanja Europske unije. Tu nam je, dakako, od velike pomoći praksa Suda Europske unije.

Prvi korak sastoji se u utvrđivanju je li u pojedinom slučaju riječ o poduzetniku. Bitno je napomenuti da pojam "poduzetnik" nije definiran odredbama Ugovora te je za njegovo shvaćanje potrebno okrenuti se sudskoj praksi i drugim službenim dokumentima Europske unije. Polaznu točku u tom smislu predstavlja odluka Suda Europske unije u predmetu Höfner, vezanom uz zaštitu tržišnog natjecanja. U tom slučaju Sud je odredio da se poduzetnikom smatra svaki subjekt koji je uključen u određenu gospodarsku djelatnost, bez obzira na pravni status (primjerice, javni ili privatni) tog subjekta i njegov način financiranja. ${ }^{33}$ Navedena definicija vrlo je široka te u praksi može obuhvatiti svaku osobu koja obavljanjem gospodarske djelatnosti sudjeluje u prometu usluga i roba. Riječ je o funkcionalnom pristupu, u kojem je naglasak na djelatnosti koju obavlja subjekt, pri čemu se uzima u obzir ukupnost svih činjenica i gospodarskih okolnosti slučaja. ${ }^{34}$

Međutim, iz prakse Suda teško je detektirati i upotrijebiti univerzalni kriterij prema kojem bismo u svakom slučaju mogli nedvojbeno utvrditi je li riječ o poduzetniku u smislu prava EU-a. ${ }^{35}$ Jedan od kriterija koji se mogu spomenuti jest socijalna svrha odnosno funkcija subjekta. Navedeni kriterij prvi put je, kao relevantan, spomenut u predmetu Poucet i Pistre, ${ }^{36}$ u kontekstu javnog socijalnog osiguranja. U tom predmetu Sud je utvrdio da obvezni sustav javnog socijalnog osiguranja zbog svoje socijalne funkcije ne predstavlja gospodarsku djelatnost prema pravu

32 Stanković, D., op. cit., str. 57.

3 Klaus Höfner and Fritz Elser v Macrotron GmbH, C-41/90 od 23. travnja 1991.

34 Sokol, T., Staničić, F., „Pravni položaj Katoličke crkve kao gospodarskog subjekta u pravu Europske unije i hrvatskom pravu“, Zbornik Pravnog fakulteta u Zagrebu, vol. 68 (2018.), 1, str. 33.

35 Tako i ibid., str. 34.

36 Christian Poucet v Assurances Générales de France and Caisse Mutuelle Régionale du LanguedocRoussillon, C-159/91 i C-160/91 od 17. veljače 1993. 
Europske unije te se osiguravatelji u takvom sustavu ne smatraju poduzetnicima. ${ }^{37}$ Osim navedena dva kriterija, pri određivanju je li riječ o poduzetniku bitno je i pitanje ostvarivanja dobiti. Kao i prethodni, ni taj kriterij nije apsolutan, već njegova prisutnost u nekim situacijama upućuje na nepostojanje gospodarske aktivnosti, a u nekima ne. ${ }^{38}$ Idući kriterij koji se uzima u obzir pri isključenju primjene pravila o tržišnom natjecanju i državnim potporama jest kriterij državne kontrole. Navedeno se može vidjeti u odluci Suda Europske unije u predmetu Freskot. ${ }^{39} 40$

Ipak, iz navedenoga može se izvući općeniti zaključak da ključnu ulogu imaju propisi pojedine države koji u nekom segmentu praktički isključuju tržišno natjecanje. Država to može napraviti ili na način da potpuno zabrani konkurenciju i uspostavi zakonski monopol ili da stvori pravni okvir koji obavljanje određene aktivnosti čini posve neisplativim za privatne subjekte ${ }^{41}$ Kada postoji stvarno tržišno natjecanje između određenog subjekta (čak i ako navedeni subjekt ima poseban pravni status ili predstavlja subjekt javnog prava) i privatnih osoba (fizičkih ili pravnih), može se zaključiti da je riječ o gospodarskoj djelatnosti na koju se primjenjuju propisi EU-a o tržišnom natjecanju i državnim potporama..$^{42}$ U takvoj se situaciji subjekti koji se kroz pružanje dobara i usluga natječu s drugim subjektima na tržištu i snose rizik poslovanja smatraju poduzetnicima. Navedeno isključenje tržišnog natjecanja posebno je primjenjivo u slučaju subjekata koji ispunjavaju određenu socijalnu funkciju, djeluju prema načelu solidarnosti, ne ostvaruju dobit te čije su aktivnosti u bitnim elementima određene zakonodavstvom države članice Unije. ${ }^{43}$

Pitanje obavljanja gospodarske djelatnosti i primjenjivosti tržišnih propisa EU-a nije ograničeno isključivo na sudsku praksu u sferi zaštite tržišnog natjecanja i državnih potpora. Bitnu ulogu ovdje igraju i pravila o slobodi kretanja usluga na unutarnjem tržištu Unije. Ključan predmet koji je utvrdio kriterije Suda Europske unije u ovom području jest Humbel, ${ }^{44}$ o slučaju francuskog državljanina koji je išao u srednju školu u Belgiji te je morao platiti školarinu (upisninu) koju nisu morali platiti belgijski državljani. Bila je riječ o očitoj diskriminaciji, no, da bi

37 Sokol, T., Staničić, F., op. cit., str. 34. Dodatno, u predmetu FENIN (Federación Nacional de Empresas de Instrumentación Científica, Médica, Técnica y Dental (FENIN) v Commission of the European Communities T-319/99) utvrđen je i drugi kriterij - onaj solidarnosti. Bila je riječ o tužbi zbog predugih rokova plaćanja protiv EK od strane udruženja distributera medicinskih proizvoda i opreme koje su prodavali španjolskim bolnicama. Bila je riječ o jedinstvenom nacionalnom zdravstvenom sustavu $u$ kojem nije postojala distinkcija između pružatelja zdravstvenih usluga i fonda koji plaća navedene usluge. Premda je španjolski zdravstveni sustav kupovao dobra na tržištu, navedena transakcija sama po sebi nije značila da taj sustav obavlja gospodarsku djelatnost. Bitna je bila svrha za koju su dobra kupljena, a ta svrha bila je socijalna. Osim navedenog, ključnim se pokazala činjenica da je španjolski zdravstveni sustav utemeljen na načelu solidarnosti, s obzirom na to da je pretežno financiran od strane države i da je pacijentima pružao usluge besplatno. Vidi u: ibid., str. 35 .

38 Ibid., str. 36.

39 Freskot AE v Elliniko Dimosio, C-355/00 od 22. svibnja 2003.

40 Sokol, T., Staničić, F., op. cit., str. 36.

41 Ibid., str. 37.

42 Ibid.

43 Ibid.

44 Belgian State v René Humbel and Marie-Thérèse Ede, C-263/86 od 27. rujna 1988. 
pravo EU-a bilo primjenjivo, među ostalim se moralo utvrditi je li riječ o slobodi pružanja usluga na unutarnjem tržištu EU-a, odnosno o gospodarskoj djelatnosti. Sud je utvrdio da je riječ o gospodarskoj djelatnosti samo u slučaju usluga koje se uobičajeno pružaju uz određenu naknadu, pri čemu naknada predstavlja ekonomsku protučinidbu za uslugu koja se pruža. S druge strane, uspostavljajući i održavajući sustav javnog obrazovanja, koji se u pravilu financira iz javnog proračuna, a ne iz sredstava plaćenih od strane učenika ili njihovih roditelja, država nema namjeru izvršavati djelatnosti uz naknadu, već ispunjava zadaću koju ima prema svojem stanovništvu u socijalnom, kulturnom i obrazovnom području. Iz navedenog razloga Belgija je imala pravo naplaćivati državljanima drugih država članica višu školarinu nego svojim vlastitim državljanima. ${ }^{45}$

U predmetu Humbel nije riješeno pitanje obrazovanja što ga pružaju subjekti u privatnom vlasništvu koji se pretežno financiraju kroz školarine, kao ni visokog obrazovanja, što je od presudnog značaja za našu temu. Ipak, presudom u predmetu Wirth ${ }^{46}$ Sud Europske unije utvrdio je da tečajevi što ih pružaju obrazovne ustanove, a financiraju se privatnim sredstvima koja ne potječu od samog pružatelja usluga, predstavljaju usluge s obzirom na to da je cilj spomenutih ustanova ponuditi uslugu uz naknadu i ostvariti dobit. ${ }^{47} \mathrm{U}$ ovom kontekstu nije potrebno da navedeno financiranje osiguraju uglavnom sami učenici jer gospodarska narav određene djelatnosti ne ovisi o tome plaćaju li neku uslugu oni koji se tom uslugom koriste (dakle, mogu plaćati i roditelji). ${ }^{48}$

Sljedeći izvadak iz presude Wirth citiramo na engleskom radi preciznosti: As the Court has already emphasized in Case 263/86 Belgian State v Humbel [1988] ECR 5365, at paragraphs 17, 18 and 19, the essential characteristic of remuneration lies in the fact that it constitutes consideration for the service in question, and is normally agreed upon between the provider and the recipient of the service. In the same judgment the Court considered that such a characteristic is absent in the case of courses provided under the national education system. First of all, the State, in establishing and maintaining such a system, is not seeking to engage in gainful activity, but is fulfilling its duties towards its own population in the social, cultural and educational fields. Secondly, the system in question is, as a general rule, funded from the public purse and not by pupils or their parents. The Court added that the nature of the activity is not affected by the fact that pupils or their parents must sometimes pay teaching or enrolment fees in order to make a certain contribution to the operating expenses of the system.

U konkretnom slučaju, Sud je utvrdio da njemačka obrazovna ustanova, primarno financirana iz javnih sredstava, uz plaćanje upisnine (Gebuehren) nije

45 Sokol, T., Staničić, F., op. cit., str. 37. i 38.

46 Stephan Max Wirth v Landeshauptstadt Hannover, C-109/92 od 7. prosinca 1993.

47 Sokol, T., Staničić, F., op. cit., str. 38.

48 Vidi Herbert Schwarz and Marga Gootjes-Schwarz v Finanzamt Bergisch Gladbach, C-76/05 od 11. rujna 2007. Vidi i u ibid. U citiranoj presudi Sud se poziva i na svoju konzistentnu praksu u predmetima: Bond van Adverteerders and Others, C-352/85; Deliège, Cases C-51/96 i C-191/97; Smits and Peerbooms i Skandia and Ramstedt. 
pružatelj usluge u smislu prava EU-a. Dakle, načelno, kada država uspostavi sustav visokog obrazovanja, ona se time ne upušta u aktivnost kojom se stječe dobit, već ispunjava svoje socijalne, kulturne i obrazovne obaveze. ${ }^{49} \mathrm{Da}$ bi došao do tog zaključka Sud je smatrao relevantnim da se javno obrazovanje, u pravilu, financira iz državnog proračuna, a ne od strane učenika i njihovih roditelja. Na javnu narav takvog obrazovanja ne utječe niti činjenica da učenici ili studenti ponekad moraju platiti školarinu ili/i upisninu. Stoga se javno obrazovanje ne smatra uslugom. ${ }^{50}$ Stoga, Sud načelno stoji na stajalištu da javno visoko obrazovanje nije usluga i da se na njega ne primjenjuje Direktiva o uslugama. ${ }^{51}$

Navedena sudska praksa odgovorila je na neka pitanja, no neka je ostavila otvorenima. Prvo pitanje tiče se važnosti stjecanja dobiti kao kriterija za primjenu tržišnih pravila EU-a. U kasnijem predmetu $J u n d t^{52}$ Sud je, na tu temu, ustvrdio da i subjekti koji ne streme ostvarivanju dobiti mogu obavljati gospodarsku djelatnost pružanjem usluga.$^{53} \mathrm{U}$ tom predmetu bila je riječ o nastavniku koji je kao vanjski suradnik honorarno predavao na sveučilištu te se zbog toga radilo o pružanju usluga od strane tog nastavnika (zato što je dobio naknadu od sveučilišta kao protučinidbu za nastavu koju je odradio). ${ }^{54}$

Drugo, mnoge obrazovne ustanove financiraju se iz različitih izvora, od kojih su samo dio privatna sredstva, dok dio dolazi iz javnih izvora. Čak se i pojedini studijski programi mogu istovremeno financirati iz različitih izvora. Ako se ovome nadoda prije opisana sudska praksa koja se tiče definicije poduzetnika, jasno je da je u pojedinom slučaju vrlo teško utvrditi je li riječ o gospodarskoj djelatnosti na koju se primjenjuju tržišna pravila Europske unije ili nije..$^{55}$

\section{PRAVNA TEORIJA O PRIMJENI DIREKTIVE O USLUGAMA NA SUSTAV VISOKOG OBRAZOVANJA}

Člankom 1. Protokola br. 26 UFEU-a daje se tumačenje o tome što uključuju zajedničke vrijednosti Unije u pogledu UOGI-ja: (i) ključnu ulogu i široko diskrecijsko pravo nacionalnih, regionalnih i lokalnih tijela u pružanju, naručivanju i organiziranju usluga od općeg gospodarskog interesa u najvećoj mogućoj mjeri povezanih s potrebama korisnika, (ii) raznolikost različitih usluga od općeg gospodarskog interesa te razliku potreba i sklonosti korisnika koje mogu proizlaziti iz različitih geografskih, socijalnih i kulturnih okolnosti i (iii) visoku razinu kvalitete,

49 Rodin, S., ,Kao brodovi u noći: hrvatsko visoko obrazovanje i slobode unutarnjeg tržišta Europske unije“", Politička misao, vol. 48 (2011.), 1., str. 189.

50 Ibid.

51 Vidi i Morjin, J., „Economic Liberalisation of Education Provision within the EC \& WTO: A Human Rights Perspective“, Croatian Yearbook of European Law nad Policy, vol. 2 (2006.), str. 100.

52 Hans-Dieter Jundt and Hedwig Jundt v Finanzamt Offenburg, C-281/06 od 18. prosinca 2007.

53 Sokol, T., Staničić, F., op. cit., str. 38.

54 Vidi i Rodin, S., op. cit., str. 190.

55 Sokol, T., Staničić, F., op. cit., str. 38. 
sigurnosti i financijske dostupnosti, jednak tretman i promicanje univerzalnog pristupa i pravâ korisnikâ. Nasuprot tomu, člankom 2. tog protokola potvrđuje se također načelo prema kojem odredbe Ugovorâ ni na koji način ne utječu na nadležnost država članica za pružanje, naručivanje i organiziranje negospodarskih usluga od općeg interesa. ${ }^{56}$

I teorija se slaže da se Direktiva o uslugama primjenjuje samo na gospodarske usluge od općeg interesa, a ne na negospodarske usluge od općeg interesa. Međutim, iako je točno da se ove dvije kategorije usluga razlikuju po ekonomskoj naknadi, teorija također navodi da je moguće visoko obrazovanje klasificirati unutar obje kategorije. ${ }^{57}$ Ipak, i teorija smatra da razlika ovisi o tipu financiranja, ${ }^{58}$ pa su tako privatna učilišta ona koja pružaju usluge koje potpadaju pod opseg Direktive o uslugama. Stoga ona uživaju zaštitu Direktive kada se nalaze na tržištu s drugim privatnim učilištima. ${ }^{59}$ Međutim, ni ta činjenica nije bez opasnosti jer je stvorila tenzije između slobodnog tržišta na obrazovnom tržištu i prava država članica da u potpunosti kontroliraju svoje sustave visokog obrazovanja i njihovu kvalitetu. Ranija teorija također je isticala da se, samo u kontekstu ekonomske integracije privatno obrazovanje može smatrati uslugom prema definiciji Suda, odnosno da se, ako se obrazovanje pruža uz naknadu, primjenjuje primarno pravo Unije. Međutim, Sud nikada nije otvoreno definirao privatno obrazovanje uslugom. ${ }^{60}$ Ono što se može istaknuti jest činjenica da je prevladavajuće tumačenje da se Direktiva o uslugama primjenjuje samo na privatno visoko obrazovanje, a ne i na javno visoko obrazovanje. ${ }^{61}$ Dakako, treba dati odgovor i na pitanje - što je javno visoko obrazovanje, tj. kako ga prepoznati. Naime, nema konsenzusa o tome kako definirati ,javno obrazovanje“. ${ }^{62}$ Je li odlučujući kriterij tko pruža obrazovanje ili da se radi o javno financiranom obrazovanju ili su odlučujuća oba navedena kriterija? Prema Rodinu, postoje sljedeći kriteriji koje je uspostavio Europski parlament: svrha aktivnosti (komercijalna ili nekomercijalna), postotak financiranja od strane javnog sektora, razinu investicije, motiviranost profitom za razliku od motiva

56 Stanković, D., op. cit., str. 58.

57 Vidi u Davies, G., The Process and Side-Effects of Harmonisation of European Welfare States, str. 19., dostupno na: http://jeanmonnetprogram.org/wp-content/uploads/2014/12/060201.pdf, pristupljeno 12. XI. 2019.

58 Morjin, J., op. cit., str. 126.

59 Ovo posebno proizlazi iz presude Suda Neri (Valentina Neri v. European School of Economics, C-153/02 od 13. studenog 2003.) u kojoj je Sud naveo da je organiziranje ,university courses“ od strane privatnog visokog učilišta ekonomska aktivnost koja potpada pod pravo Unije glede prava priznavanja akademskih stupnjeva.

60 Gori, G., op. cit., str. 383.

${ }_{61}$ Hackl, E., ,Tensions in the Policy Objectives of the European Higher Education Area? Public Good and Public Responsibility VErsus Service Liberalisation: Equality Versus Institutional Diversity“, u: Curaj, A., Scott, P., Vlaseceanu, L., Wilson, L. (ur.), European Higher Education at the Crossroads: Between the Bologna Process and National Reforms, Springer, Dordredcht, Heidelberg, New York, London, 2012., str. 88.

62 Marginson, S., Public/private in higher education: a synthesis of economic and political approaches, Centre for Global Higher Education, UCL Institute of Education, London, 2016., str. 1-22, dostupno na: https://www.researchcghe.org/perch/resources/publications/wp1.pdf, pristupljeno 10. XI. 2019. 
pokrivanja troškova, procjena koristi koje proizlaze iz lokalnog pribavljanja usluge za razliku od paneuropske javne nabave, jamstva socijalnih prava koja se promiču te promicanje socijalne inkluzije i integracije. ${ }^{63}$ Neki autori ${ }^{64}$ smatraju da u budućnosti nije vjerojatno da će Sud Europske unije ipak održati - ponajprije zbog činjenice da su danas mnoga europska sveučilišta privatna, ali ovisna o državi jer $50 \%$ ili više njihovih prihoda dolazi od države - status visokog obrazovanja kao usluge općeg interesa. ${ }^{65}$ Naime, iz ovoga slijedi da su same države odlučile prebaciti visoko obrazovanje iz suverene stvari države u poduzetnički pothvat, što bi značilo da se radi o stvari pod opsegom Direktive o uslugama ${ }^{66}$ Ovo je zanimljivo stajalište, ali budućnost će pokazati dvije stvari: a) radi li se o trendu koji će prevladati i b) hoće li Sud temeljem toga promijeniti svoju praksu. Međutim, i iz ovakvog stajališta može se iščitati uvjet da bi se radilo o tržišnim sferama - privatno financiranje. Činjenica jest da je u Europi općenito prisutan trend smanjenog financiranja u visokom obrazovanju i da se javne institucije okreću i drugim izvorima financiranja. ${ }^{67}$ Izražen je trend pada javnog financiranja, prouzročen financijskom krizom i drugim nepovoljnim kretanjima javnih financija tako da je u nekim zemljama u razdoblju 2008. - 2012. zabilježen pad javnog financiranja od preko $10 \%$ (Latvija, Litva, Češka Republika, Grčka, Mađarska, Italija, Irska, Island, Portugal, Španjolska, Nizozemska), a u nekima do $10 \%$ (Engleska, Škotska, Irska, Estonija, Nizozemska, Island) ${ }^{68} \mathrm{U}$ posljednje vrijeme u europskim zemljama uz tradicionalno ${ }^{69}$ značajno financiranje iz javnih izvora, sve značajnije postaje financiranje i iz drugih izvora kao što su: školarine, financiranje kroz pružanje usluga, financiranje iz ugovora s privatnim sektorom, financiranje iz donacija, financiranje iz investicijskih aktivnosti, financiranje iz fondova Europske unije i sl. Modeli financiranja visokog obrazovanja u europskim zemljama razlikuju se upravo po omjerima i načinima javnog financiranja, financiranja iz vlastitih izvora visokih učilišta i financiranja iz

63 Rodin, S., op. cit., str. 190.

64 Vidi u: Wageningen, A., „Higher Education as a Service: Denying the Obvious“, u: Sin, C., Tavares, O., Cardoso S. J., Rosa M., (ur.), op. cit., str. 255-286.

65 Vidi i u Hackl, E., op. cit., str. 89.

66 Ibid.

67 O tome vidi Pruvot, E. B., Estermann, T., „European Universities Diversifying Income Streams“, u: Curaj, A., Scott, P., Vlaseceanu, L., Wilson, L. (ur.), op. cit., str. 709-726. Vidi i Barić V., Obadić A., „Odnos javnih i privatnih ekonomskih učilišta - svjetski trendovi i praksa u Hrvatskoj“, u: Cavrak, V., Gelo T. (ur.), Ekonomsko obrazovanje u Republici Hrvatskoj-jučer, danas, sutra, Zagreb, 2013. , str. 60. i dalje.

${ }_{68}$ Vašiček, V., Dragija, M., „Modeli financiranja visokog obrazovanja i primjena u Republici Hrvatskoj“, u: Čavrak, V., Gelo T. (ur.), op. cit., str. 119.

69 Treba istaknuti da ne postoji unificirani model financiranja visokog obrazovanja u zemljama Unije već svaka zemlja ima svoj model u kojem se koriste različite kombinacije instrumenta financiranja. Unutar zemalja EU-a najčešće se pojavljuju sljedeći instrumenti financiranja institucija visokog obrazovanja:

- sporazumi o ciljevima (engl. perfomance agreement),

- osnovni proračuni (engl. global budget),

- proračuni utemeljeni na formuli (engl. formula based budget) $\mathrm{i}$

- školarina/ naknada za studiranje (engl. tuition/ study fee).

Vidi u: ibid., str. 123. 
različitih međunarodnih fondova. ${ }^{70} \mathrm{No}$, čini li ih to poduzetnicima u smislu tržišnog natjecanja i primjene Direktive o uslugama?

Istaknuli bismo zanimljiv stav prema kojemu će ulogu i primjenu Direktive o uslugama definirati same države članice..$^{71}$ Ako one ne preuzmu aktivnu ulogu, vjerojatno je da će Sud Europske unije odlučiti na način koji će pojačati integraciju i posljedično podržati primjenu Direktive o uslugama i regulaciju tržišta. ${ }^{72}$

Treba naglasiti i da je samom Direktivom o uslugama izrijekom propisano da se ona primjenjuje samo na usluge koje se pružaju u zamjenu za ekonomsku naknadu. Pritom Direktiva dalje navodi kako usluge od općeg interesa nisu obuhvaćene u definiciji iz članka 50. Ugovora o funkcioniranju Europske unije te stoga ne ulaze u područje primjene ove Direktive. Također je propisano kako se ona ne primjenjuje niti na negospodarske usluge od općeg interesa, pa bi se moglo zaključiti da se primjenjuje na gospodarske usluge od općeg interesa. Ukratko, moglo bi se zaključiti da je ključni kriterij prema kojemu bismo mogli zaključiti primjenjuje li se Direktiva o uslugama onaj radi li se o ,poduzetniku“ u smislu prava tržišnog natjecanja Europske unije. Tu nam je, dakako, od velike pomoći praksa Suda europske unije.

U samoj se Direktivi o uslugama navodi: U skladu sa sudskom praksom Suda potrebno je na pojedinačnoj osnovi ocijeniti mogu li se određene djelatnosti, posebno one koje su javno financirane ili ih pružaju javna tijela, smatrati ,uslugama" s obzirom na sva njihova obilježja, a posebno s obzirom na način na koji se pružaju, njihovu organizaciju i financiranje u dotičnoj državi članici. Sud smatra da ključno obilježje naknade leži u činjenici da ona predstavlja nadoknadu za dotičnu uslugu, i priznaje da to svojstvo naknade ne postoji u slučaju djelatnosti koje se, od strane države ili u njeno ime, izvode bez nadoknade u kontekstu njezinih obveza na socijalnom, kulturnom, odgojnom i pravosudnom području kao što je školovanje u okviru nacionalnog obrazovnog sustava ili upravljanje programima socijalne sigurnosti, koje ne uključuju ekonomsku aktivnost. Plaćanje naknade od strane primatelja, na primjer plaćanje školarine ili upisnine od strane učenika i studenata kao doprinos operativnim troškovima sustava, samo po sebi ne predstavlja naknadu zato što se usluga u svom bitnom dijelu financira iz državnih fondova. Ove usluge stoga nisu obuhvaćene u definiciji usluge iz članka 50. Ugovora i ne ulaze u područje primjene ove Direktive.

$70 \quad$ Ibid., str. 111.

71 Hackl, E., op. cit., str. 91.

72 Ibid. 


\section{PRIJEPORI O PRIMJENI DIREKTIVE O USLUGAMA U HRVATSKOM SUSTA VU VISOKOG OBRAZOVANJA}

Promotrimo sada pravni okvir koji uređuje sustav visokog obrazovanja u Republici Hrvatskoj. Najvažniji zakon u tom području jest Zakon o znanstvenoj djelatnosti i visokom obrazovanju (dalje u tekstu: ZZDVO). ${ }^{73} \mathrm{Uz}$ ZZDVO važni su i drugi zakoni kao što su Zakon o osiguranju kvalitete u znanosti i visokom obrazovanju, ${ }^{74}$ Zakon o hrvatskom kvalifikacijskom okviru, ${ }^{75}$ Zakon o akademskim i stručnim nazivima i akademskom stupnju, ${ }^{76}$ Zakon o studentskom zboru i drugim studentskim organizacijama, ${ }^{77}$ Zakon o priznavanju inozemnih visokoškolskih kvalifikacija, ${ }^{78}$ Zakon o Hrvatskoj zakladi za znanost ${ }^{79}$ te velik broj podzakonskih akata koje je donijelo Ministarstvo znanosti i obrazovanja (ranije i sporta). Radi se o vrlo složenom pravnom sustavu za koji neki autori smatraju da zaslužuje položaj ili podgrane upravnog prava ili čak posebne pravne grane. ${ }^{80}$ Posebno treba istaknuti da se kod „,sveučilišnog prava“ radi o iznimno specifičnom pravnom području koje predstavlja, u najmanju ruku, spoj upravnog, radnog i autonomnog „Sveučilišnog prava“. ${ }^{81} 82$ Pitanje primjene Direktive o uslugama intenziviralo se prilikom izrade Nacrta Zakona o osiguravanju kvalitete u znanosti i visokom

73 Narodne novine, br. 123/2003, 198/2003, 105/2004, 174/2004, 2/2007, 46/2007, 45/2009, 45/2009, 63/2011, 94/2013, 139/2013, 101/2014, 60/2015 i 131/2017.

74 Narodne novine, br. 45/2009. Ovaj zakon uređuje:

- osiguravanje i unapređivanje kvalitete u znanosti i visokom obrazovanju postupcima inicijalne akreditacije, reakreditacije, tematskog vrednovanja i vanjske neovisne periodične prosudbe unutarnjeg sustava osiguravanja kvalitete (audit),

- status, djelatnost i ustrojstvo Agencije za znanost i visoko obrazovanje (u daljnjem tekstu: Agencija) kao javne ustanove u Republici Hrvatskoj koja brine o osiguravanju i unapređivanju kvalitete u znanosti i visokom obrazovanju, te

- ulogu ostalih tijela koja u Republici Hrvatskoj brinu o osiguravanju i unapređivanju kvalitete u znanosti i visokom obrazovanju.

75 Narodne novine, br. 22/2013, 41/2016 - odluka Ustavnog suda Republike Hrvatske. Ovim se Zakonom uspostavlja Hrvatski kvalifikacijski okvir (u daljnjem tekstu: HKO) i uređuje njegova primjena. Nadalje se utvrđuje povezivanje HKO-a s Europskim kvalifikacijskim okvirom (u daljnjem tekstu: EQF) i Kvalifikacijskim okvirom Europskog prostora visokog obrazovanja (u daljnjem tekstu: QF-EHEA) i posredno s nacionalnim kvalifikacijskim sustavima drugih zemalja.

76 Narodne novine, br. 107/2007 i 118/2012. Ovim se Zakonom uređuju akademski i stručni nazivi i akademski stupanj te njihovo stjecanje i korištenje.

77 Narodne novine, br. 71/2007. Ovim se Zakonom uređuje pravo studenata na predstavljanje $u$ tijelima visokih učilišta, pravo na udruživanje i djelovanje studentskih organizacija na visokim učilištima, studentski izbori, izbor i djelovanje studentskog pravobranitelja te druga pitanja vezana uz djelovanje studentskih organizacija.

78 Narodne novine, br. 158/2003, 198/2003, 138/2006, 124/2009 i 45/2011. Ovim se zakonom uređuje priznavanje inozemnih visokoškolskih kvalifikacija te razdoblja obrazovanja.

79 Narodne novine, br. 117/2001, 45/2009, 92/2010 i 78/2012. Ovim se zakonom osnovala Hrvatska zaklada za znanost, utvrdila njena svrha, tijela, osnovna imovina i način financiranja.

80 Vidi Grubišić, K., „Sistematizacija pravnih normi u visokom obrazovanju i znanosti u Republici Hrvatskoj“, Zbornik Pravnog fakulteta u Zagrebu, vol. 67 (2017.), 3-4, str. 565-598.

81 O pojmu autonomnog sveučilišnog prava vidi u ibid. str. 587-590.

82 Vidi u: Staničić, F., ,Mane i nedostaci Zakona o znanstvenoj djelatnosti i visokom obrazovanju kako ih popraviti?“, u: Barbić, J. (ur.), Istine i zablude o reformi znanosti $i$ visokog obrazovanja, Hrvatska akademija znanosti i umjetnosti, Zagreb, 2019., str. 73. i 74. 
obrazovanju. Naime, u radnom Nacrtu koji nije prošao javno savjetovanje, odnosno njegovom obrazloženju ${ }^{83}$ navodi se: ,usklađuju se postupci vanjskog vrednovanja s Direktivom 2006/123/EZ o uslugama na unutarnjem tržištu, sa Standardima i smjernicama za osiguravanje kvalitete u Europskom prostoru visokog obrazovanja te ostalim dokumentima u sklopu Bolonjskog procesa“. Odnosno, taj zakon sadrži pozivanje na ,usklađivanje s Direktivom 2006/123/EZ o uslugama na unutarnjem tržištu“". Tako se u obrazloženju navodi:

„U okviru analitičkog razmatranja hrvatskih pravnih propisa te procjene usklađenosti s Direktivom 2006/123/EZ o uslugama na unutarnjem tržištu (u daljnjem tekstu: Direktiva o uslugama), koje je provelo Ministarstvo znanosti i obrazovanja u konzultaciji s Ministarstvom gospodarstva, poduzetništva i obrta te Europskom komisijom, utvrđeni su određeni elementi moguće neusklađenosti postojećeg Zakona o osiguravanju kvalitete u znanosti i visokom obrazovanju s Direktivom o uslugama. Analiza je napravljena polazeći od tumačenja da se djelatnost privatnih visokih učilišta smatra uslugom u smislu Direktive o uslugama, budući se podmirenje troškova pružanja usluge ostvaruje putem naknade te nije sufinancirano iz nekih drugih proračunskih izvora. Kao mogući elementi neusklađenosti s Direktivom o uslugama procijenjeni su zahtjevi koji se mogu smatrati nedopuštenima ili zabranjenima kao što su obveza mentorstva u kojem se inzistira da visoko učilište u osnivanju svoju uslugu obavlja u suradnji s potencijalnim konkurentima; zahtjevi prema privatnim pružateljima usluga za izradom studije o opravdanosti izvođenja studijskog programa; zahtjev kojim se određuje najmanji broj zaposlenika; brzina ishođenja suglasnosti za obavljanje djelatnosti visokog obrazovanja; ograničenja od godinu dana za pokretanje novog akreditacijskog postupka, ako postupak iz bilo kojeg razloga završi negativno; obveza podnošenja zahtjeva za izvođenje novog studijskog programa najmanje godinu dana prije početka akademske godine u kojoj će započeti izvođenje predloženog studijskog programa. Dodatno potrebno je osigurati i provedbu članka 5. i 8. Direktive o uslugama koji nalaže administrativno pojednostavljenje (svih uvjeta) i elektroničku dostupnost postupaka, konkretno vezano uz predaju zahtjeva i postupak akreditacije te posebno regulirati uvjete prema kojima visoka učilišta iz inozemstva mogu osnivati svoje podružnice u Hrvatskoj i izvoditi svoje studijske programe na teritoriju Republike Hrvatske."

Ovakvo tumačenje primjene Direktive o uslugama jedan je od razloga zašto je krovno strateško tijelo - Nacionalno vijeće za znanost, visoko obrazovanje i tehnološki razvoj (dalje u tekstu: Nacionalno vijeće) pripremilo svoj, konkurentni onome Ministarstva, Nacrt Prijedloga Zakona o postupcima vrednovanja kvalitete visokih učilišta i znanstvenih organizacija ${ }^{84}$ Sama ova činjenica (postupak bez presedana Nacionalnog vijeća!) jasno govori o dubini neslaganja oko (načina) primjene Direktive o uslugama u sustavu visokog obrazovanja u Republici

83 Tekst je bio dostupan autorima.

84 Dostupan na: https://www.nvzvotr.hr/images/stories/dokumenti_novi/Nacrt\%20Prijedloga\%20 Zakona $\% 200 \% 20$ postupcima $\% 20$ vrednovanja $\% 20 \mathrm{kvalitete} \% 20 \mathrm{vis}$-kih $\% 20 \mathrm{ucilista} \% 20 \mathrm{i} \% 20$ znanstvenih\%20organizacija\%20NVZVOTR\%2028022018.pdf, pristupljeno 11. XI. 2019. 
Izv. prof. dr. sc. Frane Staničić i izv. prof. dr. sc. Bosiljka Britvić Vetma: Primjena direktive o uslugama u... Zbornik radova Pravnog fakulteta u Splitu, god. 57, 1/2020, str. 157-177

Hrvatskoj. U relevantnom dijelu obrazloženja svoga prijedloga Nacionalno vijeće navodi:

„U okviru analitičkog razmatranja hrvatskih pravnih propisa te procjene usklađenosti s Direktivom 2006/123/EZ o uslugama na unutarnjem tržištu (u daljnjem tekstu: Direktiva o uslugama), koje je provelo Ministarstvo gospodarstva, utvrđeni su određeni elementi moguće neusklađenosti postojećeg Zakona o osiguravanju kvalitete u znanosti i visokom obrazovanju s Direktivom o uslugama. Nacionalno vijeće za znanost, visoko obrazovanje i tehnološki razvoj smatra da se Direktiva o uslugama ne može koristiti kao argument za snižavanje kriterija koji njome nisu propisani kao nedopušteni ili zabranjeni. Pored toga, Direktiva dopušta državama članicama da zadrže određene uvjete ako oni postoje zbog zaštite prevladavajucih razloga od javnog interesa. U tom smislu, Nacionalno vijeće za znanost, visoko obrazovanje i tehnološki razvoj smatra da je potrebno zadržati uvjet procjene društvene opravdanosti i usklađenosti studijskog programa s dugoročnim potrebama tržišta rada za sve studijske programe, a ne samo za one koji će se javno financirati. U članku 14. točki 5. Direktive o uslugama izrijekom je propisano da se zabrana primjene ekonomskog ispitivanja ne odnosi na zahtjeve planiranja koji nisu usmjereni na ekonomske ciljeve, ali koji su u funkciji prevladavajućih razloga od javnog interesa. Nacionalno vijeće za znanost, visoko obrazovanje i tehnološki razvoj smatra da se prevladavajući razlog od javnog interesa ogleda u posebnom interesu države da zaštiti studente, kao korisnike specifične usluge, od pružatelja usluga koji nude studijske programe koji nisu u skladu s potrebama socijalnog, gospodarskog, kulturnog, znanstvenog i tehnološkog napretka (u daljnjem tekstu: društvenim potrebama) $i$ dugoročnim potrebama tržišta rada. Odnos između potencijalnih studenata kao korisnika usluge te visokih učilišta - bila ona javna ili privatna - jest odnos koji karakterizira neravnoteža u znanju i informacijama o studijskim programima koje ta visoka učilišta nude. Potencijalni studenti su slabija strana u tom odnosu. Kako takva neravnoteža ide na štetu studenata odnosno njihovih budućih izgleda na tržištu rada, Republika Hrvatska, zadržavajući uvjet prethodne procjene društvene opravdanosti (koja uključuje kulturnu i znanstvenu opravdanost), kao i usklađenosti studijskog programa s dugoročnim potrebama tržišta rada za sve studijske programe, to ne čini zbog ekonomskih ciljeva, već zbog prevladavajućeg razloga od javnog interesa. Javni interes se iskazuje u tome što je država, koja svojom odlukom stoji iza akreditacije određenog studijskog programa, dužna zaštititi studente od pogrešne legitimacije studijskih programa odnosno od akreditacije studijskih programa za koje nema društvene potrebe i dugoročne tržišne potrebe ili se ne očekuje da će je biti. To je, sobzirom na poremećaje koji već danas postoje na tržištu rada u Hrvatskoj, nacionalni javni interes par exellence. Dodatno je bitno napomenuti da zahtjev kojim se određuje najmanji broj zaposlenika spada pod zahtjeve koji nisu zabranjeni Direktivom o uslugama. Riječ je o zahtjevu koji može biti dopušten ako je: (a) nediskriminirajući s obzirom na mjesto registriranog sjedišta, (b) opravdan prevladavajućim razlogom od javnog interesa te (c) proporcionalan (članak 15. stavci 2. i 3. Direktive o uslugama). Nacionalno vijeće smatra da se društveni interes ogleda u zaštiti studenata i odgovornosti države da 
Izv. prof. dr. sc. Frane Staničić i izv. prof. dr. sc. Bosiljka Britvić Vetma: Primjena direktive o uslugama u... Zbornik radova Pravnog fakulteta u Splitu, god. 57, 1/2020, str. 157-177

neće akreditirati studijski program ako visoko učilište nema odgovarajuće ljudske $i$ druge resurse za njegovo izvođenje. Direktiva o uslugama ne može se koristiti kao argument za snižavanje kriterija koji njome nisu propisani kao zabranjeni, a za čije propisivanje postoje legitimni prevladavajući razlozi od javnog interesa.“

Posljedično, Nacrt koji je pripremilo Ministarstvo sadrži sljedeću odredbu (čl. 2. st. 3.):

„Ovaj Zakon sadrži odredbe koje su u skladu s Direktivom 2006/123/EZ Europskog parlamenta $i$ Vijeća od 12. prosinca 2006. godine o uslugama na unutarnjem tržištu (SL L 376, 12/12/2006)“", dok nacrt koji je izradilo Nacionalno vijeće u čl. 2. sadrži samo dva stavka, a ne sadrži pozivanje na usklađivanje s Direktivom o uslugama.

Iduća točka prijepora nastala je kada je Ministarstvo znanosti i obrazovanja odlučilo pripremiti potpuno nov Zakon o znanstvenoj djelatnosti i visokom obrazovanju te oformilo ${ }^{85}$ radnu skupinu. ${ }^{86} \mathrm{Na}$ radu na izradi zakona unutar radne skupine aktualizirao se sukob mišljenja oko, ponajviše, dvije kategorije obrazovanja koje pružaju visoka učilišta - izvanrednog studija, odnosno studija uz rad te raznih programa cjeloživotnog obrazovanja. Odnosno, sukob oko toga radi li se o tržišnim kategorijama, što ovisi o tome radi li se o poduzetništvu i primjenjuje li se, posljedično, na te kategorije obrazovanja Direktiva o uslugama i na koji način. Neki smatraju da obje kategorije nedvojbeno spadaju u ,poduzetništvo“ te da bi trebala vrijediti pravila tržišnog natjecanja i da su, posljedično, javna visoka učilišta nelojalna konkurencija privatnim visokim učilištima i kod pružanja izvanrednog studija (koji na javnim visokim učilištima studenta košta bitno manje) i kod izvođenja programa cjeloživotnog učenja. Mišljenja smo da je točno da je izvođenje programa cjeloživotnog učenja tržišna kategorija iz razloga što se na tom području i javna visoka učilišta ponašaju kao poduzetnik sa svim što iz toga proizlazi: postoji stvarno tržišno natjecanje i snose rizik poslovanja. S druge strane, oba navedena kriterija ne postoje kod pružanja izvanrednog studija s obzirom na to da na tom području koje je intrinzično jezgra visokog obrazovanja nema pravog tržišnog natjecanja, unatoč činjenici da studenti plaćaju upisnine i zato što javna

85 Odlukom o imenovanju Povjerenstva za izradu Nacrta prijedloga Zakona o znanstvenoj djelatnosti i visokom obrazovanju Klasa: 023-03/18-06/00009, ur. broj: 533-03-18-0017 od 22. ožujka 2018., dopunjenu i izmijenjenu Odlukom o dopuni i izmjeni Odluke o imenovanju Povjerenstva za izradu Nacrta prijedloga Zakona o znanstvenoj djelatnosti i visokom obrazovanju, Klasa: 023-03/18-06/00009, ur. broj: 533-03-18-0020 od 17. rujna 2018. godine.

86 Također kao potez bez presedana valja navesti da je Senat Sveučilišta u Zagrebu, kao odgovor na pripremu novog ZZDVO-a od strane Ministarstva (a prema mišljenju Senata bez adekvatnog uključivanja zainteresiranih dionika) ponajprije imenovao 29-člano Povjerenstvo za razvoj i institucionalno uređenje sustava znanosti i visokog obrazovanja, Odlukom o imenovanju Povjerenstva za razvoj i institucionalno uređenje sustava znanosti i visokog obrazovanja, Klasa: 602-04/18-04/17, ur. broj: 380-020/173-17-1 od 15. svibnja 2018. godine, sa zadaćom da ,izradi nacrt prijedloga cjelovitog i usklađenog zakonskog rješenja funkcioniranja aktivnosti, procesa i institucija u sustavu znanosti i visokog obrazovanja“. Navedeno je Povjerenstvo izradilo i Senatu predložilo Nacrt Zakona o znanstvenoj djelatnosti i visokom obrazovanju, koji je Senat Odlukom, Klasa: 602-04/19-04/26, ur. broj: 380-020/284-19-1, od 14. svibnja 2019. godine i prihvatio te uputio Posebnom stručnom povjerenstvu za provedbu Strategije obrazovanja, znanosti i tehnološkog razvoja te dostavio na znanje svim rektorima sveučilišta u Republici Hrvatskoj. 
visoka učilišta ne snose nikakav rizik poslovanja na tom području. Javna visoka učilišta mogla bi predstavljali nelojalnu konkurenciju da koriste svoj prevladavajući ili monopolistički utjecaj na drugom tržištu što bi im omogućavalo da na "tržištu" izvanrednog studija idu s niskim cijenama. Kako ne postoji drugo "tržište" jer nema spora oko toga da redovni studij ne predstavlja tržište, onda iz toga slijedi da ne može biti niti nelojalne konkurencije u smislu zaštite tržišnog natjecanja. Kako će se ovaj sukob mišljenja razriješiti, za sada nam nije poznato, ali posljednja dostupna verzija ${ }^{87}$ novog ZZDVO-a ne sadrži upućivanje na usklađenost ZZDVO-a s Direktivom o uslugama.

\section{ZAKLJUČNA RAZMATRANJA}

U teoriji postoje i ovakva razmatranja: visoko obrazovanje nije intrinzično javno niti privatno i njegova regulacija, upravljanje, pružanje i financiranje predstavljaju političku i ideološku odluku. Prema tome, primjenu Direktive o uslugama i njen opseg mogu jedino definirati države članice samostalno. Naime i zaključno: u pravu tržišnog natjecanja država ima autonomiju isključiti neki sektor potpuno s tržišta tako da stvori pravni okvir koji obavljanje određene aktivnosti čini posve neisplativim za privatne subjekte. S druge strane, ona ne smije, ako postoji tržišno natjecanje, privilegirati određene subjekte na tom tržištu. ${ }^{88}$ Tako Rodin zaključuje kako je opravdano tvrditi da je visoko obrazovanje, kao neekonomska usluga od općeg interesa, izuzeto od primjene pravila o unutarnjem tržištu i tržišnoj utakmici samo u mjeri u kojoj je to nužno za ostvarivanje socijalne funkcije države. Inicijalnu prosudbu što se ubraja u takve usluge provodi država članica uz sudbeni nadzor Europskog suda. Dio obrazovanja koji se ima smatrati uslugom, odnosno za koji se ne može smatrati da je nužan za ispunjenje temeljne zadaće javne službe, u dosegu je primjene primarnog i sekundarnog prava EU-a primjenjivog na tržišne slobode i pravila o tržišnoj utakmici ${ }^{89}$ Visoko obrazovanje ima mnoge atribute javnog i privatnog dobra te je možda najbolje zadržati obje njegove karakteristike i ne odlučiti se niti za javni monopol niti za neograničeno tržišno natjecanje..$^{90}$ Prema tome, odluka o tome je li ili nije visoko obrazovanje, odnosno njegovi oblici, tržišna kategorija mora donijeti svaka država članica za sebe. Što se tiče slobode pružanja usluga, tamo gdje se obrazovanje financira primarno iz javnih sredstava, ne radi se

87 Voditelj radne skupine, državni tajnik u Ministarstvu znanosti, predstavio je (nedovršen i neraspravljen u velikom dijelu unutar Povjerenstva za izradu Nacrta ZZDVO-a) Nacrt ZZDVO-a na nizu institucija (Vijeće veleučilišta i visokih škola, Hrvatska udruga poslodavaca, Zagrebačka škola ekonomije i managementa, Nacionalno inovacijsko vijeće) te je Nacrt već prilično poznat javnosti.

88 Vidi o tome: Rodin, S., op. cit., str. 186-214.

89 Ibid., str. 192.

90 Vidi, posebno, Williams, G., „Higher Education: Public good or private commodity?“, London Review of Education, vol. 14 (2016.), 1, str. 131-141. 
o usluzi na tržištu. ${ }^{91}$ To uključuje i situacije u kojima studenti plaćaju neki oblik upisnine koji ne odražava realnu cijenu usluge..$^{92}$ Ali, ako naknada odražava realnu cijenu usluge koja se pruža, bez obzira na to što je pruža javno visoko učilište, radi se o usluzi koja potpada pod Direktivu o uslugama. ${ }^{93}$ Ipak, sigurno se može reći da ce sustav visokog obrazovanja biti najosporavaniji kao tržište. ${ }^{94}$

\section{LITERATURA}

1. Barić V., Obadić A., „Odnos javnih i privatnih ekonomskih učilišta - svjetski trendovi i praksa u Hrvatskoj“, u: Čavrak, V., Gelo T. (ur.), Ekonomsko obrazovanje u Republici Hrvatskoj - jučer, danas, sutra, Zagreb, 2013., str. 57-86.

2. Communication from the Commission to the European Parliament, the Council, the European Economic and Social Committee and the Committee of the Regions - on a renewed EU agenda for higher education, dostupno na https://eur-lex.europa.eu/ legal-content/EN/TXT/PDF/?uri=CELEX:52017DC0247\&from=DA, pristupljeno 8 . XI. 2019.

3. Davies, G., The Process and Side-Effects of Harmonisation of European Welfare States, dostupno na: http://jeanmonnetprogram.org/wp-content/uploads/2014/12/060201. pdf, pristupljeno 12. XI. 2019.

4. Đulabić, V., ,PPovelje javnih službi: pokušaj podizanja kvalitete javne uprave i jačanja uloge građana“, Zbornik Pravnog fakulteta u Zagrebu, vol. 56 (2006.), 1, str. 7-48.

5. Gori, G., Towards a EU Right to Education, Kluwer Law International, The Hague, London, Boston, 2001.

6. Grubišić, K., „Sistematizacija pravnih normi u visokom obrazovanju i znanosti u Republici Hrvatskoj“, Zbornik Pravnog fakulteta u Zagrebu, vol. 67 (2017.), 3-4, str. 565-598.

7. Hackl, E., „Tensions in the Policy Objectives of the European Higher Education Area? Public Good and Public Responsibility Versus Service Liberalisation: Equality Versus Institutional Diversity“, u: Curaj, A., Scott, P., Vlaseceanu, L., Wilson, L. (ur.), European Higher Education at the Crossroads: Between the Bologna Process and National Reforms, Springer, Dordredcht, Heidelberg, New York, London, 2012., str. 83-99.

8. Marginson, S., Public/private in higher education: a synthesis of economic and political approaches, Centre for Global Higher Education, UCL Institute of Education, London, 2016., str. 1-22, dostupno na: https://www.researchcghe.org/ perch/resources/publications/wp1.pdf, pristupljeno 10. XI. 2019.

91 Dijelom suprotno vidi u Rodin, S., op. cit., str. 191: „U svakom slučaju, države članice ne mogu isključiti čitave sektore ekonomske aktivnosti iz dosega tržišnih sloboda, pa tako i jedan dio aktivnosti visokog obrazovanja uživa zaštitu jamstava unutarnjeg tržišta EU-a. Takve će aktivnosti biti izuzete od primjene tržišnih pravila samo u mjeri u kojoj to ne utječe na ostvarivanje njihove temeljne zadaće, što se prosuđuje od slučaja do slučaja.“

92 Vidi i u ibid., str. 189.

93 Vidi slično razmišljanje u Davies, G., op. cit., str. 21.

94 Ibid., str. 61. 
9. Morjin, J., „Economic Liberalisation of Education Provision within the EC \& WTO: A Human Rights Perspective“, Croatian Yearbook of European Law nad Policy, vol. 2 (2006.), str. 99-136.

10. Pruvot, E. B., Estermann, T., „European Universities Diversifying Income Streams“, u: Curaj, A., Scott, P., Vlaseceanu, L., Wilson, L. (ur.), European Higher Education at the Crossroads: Between the Bologna Process and National Reforms, Springer, Dordredcht, Heidelberg, New York, London, 2012., str. 709-726.

11. Ravinet, P., „On Principles, Europe and Higher Education: Reflections on European Higher Education as an Intersecting Normative Space“, u: Sin, C., Tavares, O., Cardoso S.J., Rosa M. (ur.), European Higher Education and the Internal Market, Palgrawe Macmillan, London, 2018., str. 21-45.

12. Rodin, S., „Kao brodovi u noći: hrvatsko visoko obrazovanje i slobode unutarnjeg tržišta Europske unije“, Politička misao, vol. 48 (2011.), 1., str. 186-214.

13. Sokol, T., Staničić, F., „Pravni položaj Katoličke crkve kao gospodarskog subjekta u pravu Europske unije i hrvatskom pravu“, Zbornik Pravnog fakulteta u Zagrebu, vol. 68 (2018), 1, str. 31-60.

14. Staničić, F., „Mane i nedostaci Zakona o znanstvenoj djelatnosti i visokom obrazovanju - kako ih popraviti?", u: Barbić, J. (ur.), Istine i zablude o reformi znanosti i visokog obrazovanja, Hrvatska akademija znanosti i umjetnosti, Zagreb, 2019., str. 73-111.

15. Stanković, D., „Uloga postupaka javne nabave u financiranju usluga od općeg gospodarskog interesa“, Zagrebačka pravna revija, vol. 7 (2008.), 1, str. 53-69.

16. Vašiček, V., Dragija, M., „Modeli financiranja visokog obrazovanja i primjena u Republici Hrvatskoj“, u: Čavrak, V., Gelo T. (ur.), op. cit., str. 109-133.

17. Wageningen, A., ,,The Legal Constitution of Higher Education Policy and Governance of the European Union“", u: Huisman, J., de Boer, H., Dill, DD, Souto-Otero, M. (ur.), The Palgrave International Handbook of Higher Education Policy and Governance, Palgrave Macmillan, London, 2015., str. 95-113.

18. Wageningen, A., „Higher Education as a Service: Denying the Obvious“, u: Sin, C., Tavares, O., Cardoso S. J., Rosa M., (ur.), European Higher Education and the Internal Market, Palgrawe Macmillan, London, 2018., str. 255-286.

19. White Paper on services of general interest (2004.), dostupno na: https://eur-lex. europa.eu/legal-content/EN/TXT/?uri=LEGISSUM\%3Al23013b, pristupljeno 10. XI. 2019.

20. Williams, G., „Higher Education: Public good or private commodity?“, London Review of Education, vol. 14 (2016.), 1, str. 131-141. 


\section{APPLICATION OF DIRECTIVE ON SERVICES IN HIGHER EDUCATION}

Authors in this paper analyse whether Directive 2006/123/EC European Parliament and Council of 12 December 2006 on the services in the internal market and in the system of higher education is being applied. Existing theoretical observations are shown on this problem area as is the practice of the European Union Court. The authors demonstrate that the problem area is extremely complex on which there is no consensus in theory. Existing European Court practice provides answers to certain questions. However, the Court has not given answers to many questions that can be raised given concerning possible application of this Directive on the system of higher education. The synthesis of theory and practice will demonstrate in the authors' opinion, that the stated directive is not applicable to the system of public further education. That is, the authors propose that the system of further education is the exclusive prerogative of member states who independently decide on what kind of higher education system they wish to have.

Key words: higher education, private, public, financing, services 